\title{
Sustainable Agriculture: Developing a Conceptual Model for Technology Transfer*
}

\author{
Ainur K. BORANBAYEVA*, Rui Dinis SOUSA**, Dinara Zh. RAKHMATULLAYEVA****
}

\begin{abstract}
Agriculture is the world's largest industry. It is not only crucial for the well-being of the world population but also for most citizens whose prosperity is closely connected with the level of development in the agriculture industry. However, agriculture often places significant pressure on natural resources and the environment. According to the Food and Agriculture Organization, we pay an intolerable price in social and ecological terms to provide food for 7.5 billion people in the world. To be sustainable, while increasing the productivity, agriculture needs to preserve the environment and improve the social conditions of the population. The transfer of existing technology, for example, from developed countries, as well as new technology from research and development centers, can help in achieving the right balance in essential dimensions for sustainable agriculture. Building upon technology transfer models at the international level developed for the construction and the petroleum industries, we propose first a set of factors. Then, for each factor, while scrutinizing other technology transfer models at the inter-firm level, relevant sub factors were selected. The result is a conceptual model for technology transfer to be applied in the agriculture sector under a sustainable perspective.
\end{abstract}

Keywords: Technology Transfer, Agriculture, Sustainability, Channels, Performance.

\section{Introduction}

The agricultural sector has received far less attention in comparison to the financial and manufacturing sectors despite its critical role in securing food supply and the strong potential contribution of IT in agriculture (Chiasson \& Davidson, 2005). In the long term, it is necessary to focus on agriculture to increase productivity and achieve high profits while preserving the environment and improving the social conditions of a population that keeps growing. We need a sustainable agriculture.

\subsection{Sustainable Agriculture}

The concept of sustainable development emerged in the 1980s. In a 1987 report, known as the Bruntland report, the World Commission on Environment and Development defined sustainable development as a process of change in which the exploitation of resources, the direction of investments, the orientation of technological development, and institutional change are all in harmony and enhance both current and future potential to meet human needs and

* This work has been supported by FCT - Fundação para a Ciência e Tecnologia within the Project Scope: UID/CEC/00319/2019.

** Higher School of Economics and Business, Al-Farabi Kazakh National University, Almaty, Kazakhstan.

E-mail: boranbaeva7777@mail.ru

*** Information Systems Department, ALGORITMI Research Center, University of Minho, Guimaraes, Portugal.

E-mail: rds@dsi.uminho.pt

**** Higher School of Economics and Business, Al-Farabi Kazakh National University, Almaty, Kazakhstan.

E-mail: dintash76@gmail.com aspirations. In essence, sustainable development is development that meets the needs of the present without compromising the ability of future generations to meet their own needs. Agriculture should play an important role in sustainable development.

Sustainable agriculture has been defined as a sustainable farming system in which economic, social and ecological aspects are counterbalanced (Rose et al., 2019). Considering those aspects, sustainable agriculture should also promote the resilience and persistence of productive farming landscapes (Garibaldi et al., 2017).

On the economic aspects, change in overall production and stability of production have been the indicators used for economic sustainability. However, research findings in the agricultural community explain the need to balance labor productivity with social and environmental impacts (Patidar, Kumhar, Mhaske, \& Jat, 2018).

On the social aspects, a stable social system is largely based on the proper relationship between individuals and collectives. Individuals demand the satisfaction of requirements as health, safety and legality. An agricultural social system is sustainable when institutional settings allow all concerned individuals to either satisfy or improve the satisfaction of all of their physiological, security, social, esteem, and self-actualization needs while actors and institutions continuously recreate a system that allows future generations to do the same (Janker, Mann, \& Rist, 2019).

On the environmental or ecological aspects, environment has to be addressed as a set of natural capital assets (air quality, biodiversity, etc.) particularly assuring an efficient use of non-renewal resources while integrating appropriate natural biological cycles and controls. Conservation efforts should reflect the efficient and sustainable allocation of environmental assets(Aldy, Hrubovcak, \& Vasavada, 1998).

As stated in by the European Sustainable Development Initiative in Agriculture (EISA), we need an efficient, productive, 
environmentally friendly and socially responsible agriculture.

The capacity of the agricultural sector to meet economic, social and environmental demands partially depends on the availability and adoption of technology. We should support research and development in sustainable technologies as well as facilitate technology transfer while providing incentives to encourage adoption of technology in the agricultural sector (Aldy et al., 1998).

\subsection{Technology Transfer}

Technology transfer is a complex process consisting of several elements, mechanisms and stages. The concept of the transfer of technology was used for the first time in the 1940s. Formal research in the field of technology transfer began with a study of technology conducted by European sociologists (Rogers, 2003).

Transfer technology can be conceptualized as a communication process where gaps between foreign and local environments will affect the efficiency of inter-firm communication and the overall effectiveness of the transfer technology process (Williams and Gibson, 1990). It is a movement of know-how and technical knowledge from one organizational setting to another allowing for knowledge sharing (Wang, Wang, \& Liang, 2014). The effective use and distribution of know-how is the basis for the transfer of technology that occurs in accordance to local conditions (Kaynak, 1985). It can involve moving a technological innovation from an $\mathrm{R} \& \mathrm{D}$ organization to a receptor organization (Rogers, 2003).

Overall, transfer technology is a complex process involving the movement of technologies, knowledge, innovative services and products at several levels: intra-firm level (within organizations, between departments); inter-firm level (within countries, between organizations); and international level (between countries).

\section{Overview of a Selection of Technology Transfer Models}

For the several levels at which the transfer technology can take place, we can find illustrating models in the literature. A model for intra-firm technology transfer has been proposed having as an example a British cable manufacturer (Malik, 2002).Typical problems have been found showing business units not interested in R\&D developments. This could be due to cost factors or poor communication between technology senders and receivers, or as a result of the 'not invented here syndrome'and problems simply arising from lack of resources. An investigation into why intra-firm knowledge transfers can be so difficult points to issues such as: lack of motivation; lack of absorptive capacity; lack of retentive capacity of recipients; formalized structures and systems; lack of numerous individual exchanges; and an arduous (i.e., laborious and distant) relationship between the transfer partners (Szulanski, 1996).

For the inter-firm level technology, one of the most cited models is the contingent effectiveness model of technology transfer (Bozeman, 2000), recently updated (Bozeman, Rimes, \& Youtie, 2015). In this model, five categories of technology transfer effectiveness determinants are considered: transfer agent, transfer media, transfer object, demand environment and transfer recipient. To deal with these parties with multiple goals, the effectiveness of the process is considered in terms of multiple criteria: out-the-door (was anything transferred?), market impact, economic development, political advantage, development of scientific and technical human capital, opportunity cost considerations and public value.

At the inter-firm level, circumscribed to a particular industry, the information technology industry, another study investigates 62 Korean firms involved in technology transfer for IT equipment to find the factors affecting on-time completion of technology transfer. Unlike the other studies, this one examines the stages of the processof technology transfer to determine which factors act as barriers to the timely completion of technology transfer for suppliers and buyers in accordance with technology transfer agreements(Lee, Kim, Kim, Kim, \& Ahn, 2018).

For international technology transfer, literature provides studies on some industries but not the agriculture one. A first study involves 201 petroleum industry professionals in Libya to evaluate the technology transfer performance in a model that includes support, infrastructure, learning capability and environment. Government support of petroleum industry technology has been identified as an important consideration in the success of a technology transfer process as it has an impact on several other influential factors (Mohamed, Sapuan, Megat Ahmad, Hamouda, \& Hang Tuah Bin Baharudin, 2012).

A second study involves 162 construction industry professionals in Thailand to evaluate the transfer technology value added in a model that includes transfer and learning environments, and transferor and transferee characteristics. Building relationships (i.e. trust, understanding and communication) between the transferor and transferee was determined to be the key predictor of technology transfer-induced value creation for the construction sector (Waroonkun \& Stewart, 2008).

\section{Developing a Conceptual Model to Technology Transfer}

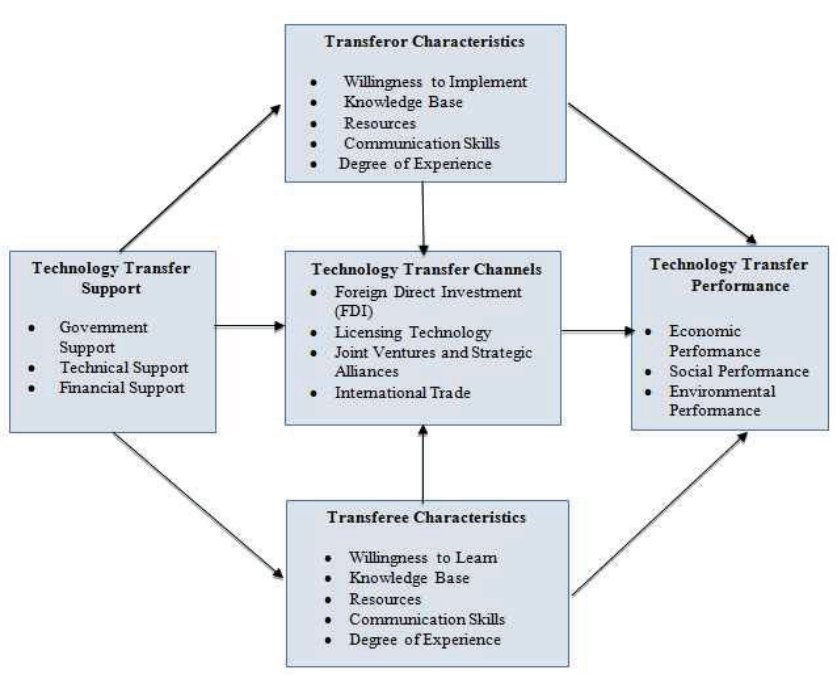

Figure 1: Conceptual model for technology transfer in sustainable agriculture industry 
Having studied the aforementioned models, we have a proposal for modeling technology transfer in the agriculture sector under the perspective of sustainable development (Fig.1.).

Not only there is a lack of proper attention to the process of technology transfer in the agriculture sector, but also that process has to be considered under a sustainable perspective. This means that the outcome of the process, designated as performance or value added, has to consider sustainability.

For our proposal, we built upon the models for international technology transfer mentioned in the previous section, one in the construction industry and the other in the petroleum industry. We kept technology transfer performance for the outcome of the process, and technology transfer support as an antecedent, both from the model for technology transfer in the Libyan petroleum industry (Mohamed et al., 2012). Transferor and transferee characteristics were borrowed from the model for international technology transfer in construction industry (Waroonkun et al., 2008).We added a new factor, technology transfer channels, somehow related to transfer media as presented in the contingent effectiveness model of technology transfer (Bozeman et al., 2015). For each one ofthe factors, we evaluated the existing set of sub factors, keeping, removing and adding them according to their importance for sustainable development, namely, in the agricultural sector.

\subsection{Technology Transfer Performance}

Instead of just focusing on economic performance as shown in the model for petroleum industry, we add the social and environmental dimensions. The assessment of a country performance cannot be limited to a single dimension, either economic or non-economic (Cracolici, Cuffaro, \& Nijkamp, 2010). For sustainable development in agriculture, the three dimensions have to be considered simultaneously. Therefore, economic, social and environmental performances have to be assessed as a result of technology transfer for sustainable agriculture.

\subsection{Transferor and Transferee Characteristics}

Transferor and Transferee Characteristics are two factors borrowed from the Conceptual Model for International Technology Transfer in Construction Projects (Waroonkun et al., 2008). They are similar to what had alreadybeen proposed, respectively, as Transfer Agent and Transfer Recipient in the Contingent Effectiveness Model of Technology Transfer (Bozeman, 2000; Bozeman et al., 2015). As a shared responsibility between the transferor and the transferee (Waroonkun, Rodney, Stewart, Waroonkun, \& Stewart, 2008), technology transfer requires from them a "knowledge base" and "resources", both to support the implementation by the transferor and adoption and acceptance of technology by the transferee. On the side of the transferor, we need to assure the "willingness to implement" while on the side of the transferee, we need to assure the "willingness to learn"on how to take advantage of the technology (Waroonkun et al., 2008). One factor that is very important is communication skills since the transfer technology process should be conceptualized as a communication process. Therefore, to avoid gaps of understanding that may affect the overall effectiveness of the process, both transferor and transferee should possess good communication skills. In addition, the degree of experience for both transferor and transferee in participating and fostering partnerships, namely, at the international level, would very important (Lin \& Berg, 2001).

\subsection{Technology Transfer Support}

Technology Transfer Support is a borrowed construct from the Conceptual Model for Technology Transfer in the Libyan oil industry (Mohamed et al., 2012). It is a factor that addresses, in particularly, the government support quite important to encourage the international transfer of technology with adequate policies (Hoekman, Maskus, \& Saggi, 2005). This type of support has also been covered through factors designated as "transfer environment" in the conceptual Model for International Transfer Technology in construction Projects (Waroonkun etal., 2008). Among other factors affecting on-time completion of technology transfer, technical support and financial support have been pointed out, required to facilitate the adoption of what is usually presents a high level of complexity for the transferees (Lee et al., 2018).

\subsection{Technology Transfer Channels}

Technology Transfer Channels should cover the most important channels through which a technology developed in one location, namely, a developed country, can be transferred to another location, a developing country. Unlike other models for international technology transfer (Mohamed et al., 2012; Waroonkun et al., 2008), our model proposes the channels as a key ingredient for the success of international technology transfer, somehow close to transfer media between the transfer agent and the transfer recipient in the contingent effectiveness model of technology transfer (Bozeman et al., 2015). Foreign Direct Investment (FDI) and international trade can be among the most important of those channels (Kneller, Pantea, \& Upward, 2009; Wie, 2005). Licensing technology can be also a major channel, especially when the licensor intends to prevent the licensee of becoming a competitor in the future and want to be in control of the technology transfer. It can be also a way of developing the technology in a foreign market before moving to FDI (Raj, n.d.). A more balanced channel for both the transferor and transferee than licensing technology can be joint ventures and strategic alliances, legal partnerships at the international level, that allow the transferor to better deal with regulatory, cultural, or other complexities when entering foreign markets (Jiang, Keller, Qiu, \& Ridley, 2018)

\section{Conclusion}

The new, 17 Sustainable Development Goals (SDGs), unanimously approved by more than 190 world leaders in the United Nations Assembly, in 2015, for the year 2030, are supposed to drive policymaking on both the national and local scale towards sustainability in the coming years. To achieve the SDGs, agriculture needs to be transformed under an integrated approach to 
sustainability. To achieve it at an international, global level, technology transfer from developed to emerging and developing economies can play a significant role as enabler and accelerator of a desired convergence.

The proposed model for international technology transfer moves away from the focus on profitability, financial performance, usually used to assess the result oftechnology transfer, to include other dimensions, the environmental and social ones. Considering only financial performance can lead to the deterioration of the environment as well of the living conditions of the world population. Therefore, a successful technology transfer should balance economic, environmental and social performances. Building upon technology transfer models at the international level developed for the construction and the petroleum industries, antecedents such as technology transfer support, transferor and transferee characteristics were borrowed, but we included transfer technology channels as another key factor. As a research in progress, we will now work on the operationalization of the model so it can be applied for sustainable development, namely, in the agriculture industry.

\section{References}

Aldy, J. E., Hrubovcak, J., \& Vasavada, U. (1998). The role of technology in sustaining agriculture and the environment. Ecological Economics, 26(1), 81-96. https://doi.org/10.1016/S0921-8009(97)00068-2

Bozeman, B. (2000). Technology transfer and public policy: A review of research and theory. Research Policy, 29(4-5), 627655. https://doi.org/10.1016/S0048-7333(99)00093-1

Bozeman, B., Rimes, H., \& Youtie, J. (2015). The evolving state-of-the-art in technology transfer research: Revisiting the contingent effectiveness model. Research Policy, 44(1), 34-49. https://doi.org/10.1016/J.RESPOL.2014.06.008

Chiasson, M. W., \& Davidson, E. (2005). Taking Industry Seriously in. MIS Quarterly, 29(4), 591-605.

Cracolici, M. F., Cuffaro, M., \& Nijkamp, P. (2010). The Measurement of Economic, Social and Environmental Performance of Countries: A Novel Approach. Soc Indic Res, 95, 339-356. https://doi.org/10.1007/s1 1205-009-9464-3

Garibaldi, L. A., Gemmill-Herren, B., Annolfo, R. D., Graeub, B. E., Cunningham, S. A., \& Breeze, T. D. (2017). Farming Approaches for Greater Biodiversity, Livelihoods, and Food Security. Trends in Ecology \& Evolution, 32(1), 68-80. https://doi.org/10.1016/j.tree.2016.10.001

Hoekman, B. M., Maskus, K. E., \& Saggi, K. (2005). Transfer of technology to developing countries: unitarel and multilateral policy options. World Development, 33(10), 1587-1602. Retrieved from http://econ.worldbank.org.

Janker, J., Mann, S., \& Rist, S. (2019). Social sustainability in agriculture - A system-based framework. Journal of Rural Studies, 65, 32-42. https://doi.org/10.1016/J.JRURSTUD.2018.12.010

Jiang, K., Keller, W., Qiu, L. D., \& Ridley, W. (2018). Joint ventures and technology transfer in China. Retrieved 29 May 2019, from VOX, CEPR Policy Portal website: https://voxeu.org/article/joint-ventures-and-technology-transfer-china

Kaynak, E. (1985). Transfer of technology from developed to developing countries: some insights from Turkey. Technology Transfer, 1, 155-176.
Kneller, R., Pantea, S., \& Upward, R. (2009). Which International Technology Transfer Channels are Effective in Raising Firm Productivity and What Role for Policy?Retrieved from http://www.etsg.org/ETSG2009/papers/pantea.pdf

Lee, S., Kim, B. S., Kim, Y., Kim, W., \& Ahn, W. (2018). The framework for factors affecting technology transfer for suppliers and buyers of technology in Korea. Technology Analysis and Strategic Management, 30(2), 172-185. https://doi.org/10.1080/09537325.2017.1297787

Lin, B., \& Berg, D. (2001). Effects of cultural difference on technology transfer projects: an empirical study of Taiwanese manufacturing companies. International Journal of Project Management, 19, 287-293.

Malik, K. (2002). Aiding the technology manager: a conceptual model for intra-firm technology transfer. Technovation, 22(7), 427-436. https://doi.org/10.1016/S0166-4972(01)00030-X

Mohamed, A. S., Sapuan, S. M., Megat Ahmad, M. M. H., Hamouda, A. M. S., \& Hang Tuah Bin Baharudin, B. T. (2012). Modeling the technology transfer process in the petroleum industry: Evidence from Libya. Mathematical and Computer Modelling, 55(3-4), 451-470. https://doi.org/10.1016/j.mcm.2011.08.025

Patidar, J., Kumhar, B., Mhaske, S., \& Jat, S. (2018). Importance of Sustainable Agriculture in Tribal Community of India. International Journal of Bio-Resource and Stress Management, 9(2). Retrieved from https://eds.a.ebscohost.com/eds/pdfviewer/ pdfviewer?vid=2\&sid=3473d6f1-d8f3-4746-8626-187837245b99\% 40sdc-v-sessmgr03

Raj, N. (n.d.). 4 Most Important Channels of Technology Transfer in International Technology Environment. Retrieved 29 May 2019, from http://www.shareyouressays.com/knowledge/4-mostimportant-channels-of-technology-transfer-in-international-technolo gy-environment/114440

Rogers, E. M. (2003). Diffusion of innovations (5th ed). Retrieved from https://www.d.umn.edu/ lrochfor/ireland/dif-of-in-ch06.pdf

Rose, D. C., Sutherland, W. J., Barnes, A. P., Borthwick, F., Ffoulkes, C., Hall, C., $\square$ Dicks, L. V. (2019). Integrated farm management for sustainable agriculture: Lessons for knowledge exchange and policy. Land Use Policy, 81, 834-842. https://doi.org/10.1016/J.LANDUSEPOL.2018.11.001

Szulanski, G. (1996). Exploring Internal Stickiness: Impediments to the Transfer of Best Practice Within the Firm. Strategic Management Journal, 17, 27-43. Retrieved from http://www.jstor.org/about/terms.html.

Wang, Z., Wang, N., \& Liang, H. (2014). Knowledge sharing, intellectual capital and firm performance. Management Decision, 52(2), 230-258. https://doi.org/10.1108/MD-02-2013-0064

Waroonkun, T., Rodney, A. E., Stewart, A., Waroonkun, T., \& Stewart, R. A. (2008). Modeling the international technology transfer process in construction projects: evidence from Thailand. J Technol Transfer, 33, 667-687. https://doi.org/10.1007/s10961-007-9043-1

Waroonkun, T., \& Stewart, R. A. (2008). Modeling the international technology transfer process in construction projects: Evidence from Thailand. Technology Transfer, 33(6), 667-687. https://doi.org/10.1007/s10961-007-9043-1

Wie, T. K. (2005). The Major Channels of International Technology Transfer to Indonesia: An Assessment. Journal of the Asia Pacific Economy, 10(2), 214-236. https://doi.org/10.1080/13547860500071493 